811.163.41'374

811.163.41’373.7:811.134.2’373.7

https://doi.org/10.18485/msc.2018.47.1.ch31

Анета Г. ТРИВИЋ*

Оригинални научни рад

Универзитет у Крагујевцу

Филолошко-уметнички факултет

Примљен: 11. 11. 2017.

Прихваћен: 27. 12. 2017.

\title{
УЛОГА СРПСКИХ РЕЧНИКА У \\ КОНТРАСТИВНОЛИНГВИСТИЧКИМ ИСТРАЖИВАњИМА \\ НА ПЛАНУ СРПСКОГ И ШПАНСКОГ ЈЕЗИКА
}

\begin{abstract}
У раду испитујемо улогу коју једнојезични (дескриптивни и фразеолошки) речници српског језика имају у контрастивнојезичким истраживањима која се баве фразеолошким јединицама. Кроз призму односа српског и шпанског језика утврђујемо могућности за изградњу паралелних корпуса и указујемо на микроструктуралне специфичности српских и шпанских речника. Како је број речничких издања у ова два језика непропорционалан, настојимо да постигнемо извесну сразмерност међу речницима сличне структуре и намене. Кроз садржински и формални опис одредница спецификујемо врсту информације коју речници доносе и правимо критички осврт на питање њихове документованости, репрезентативности и актуелности навођених примера. Закључак је да су српски речници незаобилазно средство у анализама контрастивне природе и да представљају примарни извор за формирање грађе. У истраживањима оријентисаним ка савременим језичким формама ова основна речничка грађа допуњује се изразима из живог језика чија се употреба потврђује претрагом електронских корпуса.

Кључне речи: лексикографија, дескриптивни и фразеолошки речник, речничка микроструктура, корпус, контрастивна анализа, српски језик, шпански језик.
\end{abstract}

\section{1. Српски и шпански речници у контрастивнојезичким истраживањима}

У истраживањима контрастивнолингвистичке природе која теже да пруже паралелан опис два језика на основу поређења одређених појава, улога граматика и речника је веома важна. Истраживања која за циљ имају опис појава из области лексикологије и фразеологије неминовно се базирају на

*anetatrivic@gmail.com 
речницима. ${ }^{1}$ Први корак у поступку поређења појава и јединица из два језика представља утврђивање компарабилности или упоредивости (Ђорђевић 2004: 53). Поред њега, треба разрешити и друга теоријско-методолошка питања контрастивне анализе: на првом месту проблем избора лингвистичког модела или теорије, а затим и проблем дубине и ширине контрастирања (Ђорђевић 1983: 19). Сви ови проблеми настају „из методолошке недорађености 'контрастивне анализе' и 'контрастивне лингвистике'” (Михајловић 1970: 339), и решавају се „онда када се одговори на три основна питања: шта, како и колико поредити" (Станковић 2012: 383).

Када се определимо за тему истраживања и одредимо предмет поређења, приступамо одабиру грађе на којој ће се вршити упоређивање, односно елаборацији корпуса. Будући да извори из којих се преузима материјал за грађу представљају неопходну потврду употребе језичких јединица које се планирају анализирати, овде се поставља питање њиховог одабира. Ако, на пример, желимо обрадити фразеолошке јединице из одређеног тематског поља на плану српског и шпанског језика, за прикупљање фразеолошке грађе најадекватнијим се показују једнојезични речници, како опште намене тако и фразеолошки. Иако постоје двојезични речници српског и шпанског језика, они углавном нису обимни и информација коју пружају састоји се из преводилачког еквивалента.

У српском језику су то референтни дескриптивни речници, тзв. једнотомник и шестотомник, односно Речник српскога језика Матице српске (PMC) и Речник српскохрватскога књижевног језика (PMC/MX) Матице српске и Матице хрватске. Посебно место у српској једнојезичној лексикографији заузима још увек недовршени пројекат Српске академије наука и уметности Речник српскохрватског књижевног и народног језика. Од једнојезичних фразеолошких речника на располагању имамо Фразеолошки речник српског језика Ђорђа Оташевића (ФРСЈ) из 2012. године, као и Фразеолошки рјечник хрватскога или српскога језика (FRHSJ) Јосипа Матешића, који је изашао тридесет година раније. Једнојезични дескриптивни и фразеолошки речници шпанског језика далеко су бројнији. У шпанској лексикографији се општи дескриптивни речници ажурирају релативно често, а речници савременог шпанског језика који су данас незаобилазно средство у лингвистичким истраживањима и у језичкој настави су: Речник Шпанске краљевске академије (DRAE), Речник Марије Молинер (DUE), Речник Малдонада Гонсалеса, тзв. Клаве речник (CLAVE) и Речник Мануела Сека и сарадника (DEA). Као

\footnotetext{
${ }^{1}$ У настави језика речници такође представљају веома важно средство за рад, мада се последњих година сусрећемо са новим генерацијама студената који никада нису користили штампане речнике. Они за проверу значења речи готово искључиво користе електронске корпусе, платформе и речнике (попут wordreference.com, dictionary.reverso.net, dictionary.com итд.) уз образложење да су им ови извори доступнији и да им је за њихово коришћење довољно да знају један светски језик (у данашње време то је углавном енглески). Овде су у предности студенти тзв. великих или светских језика (који су по правилу обухваћени електронским издањима), док студенти мањих језика, попут српског, још увек немају овакве могућности.
} 
и дескриптивни речници српског језика, и ови речници уједно служе и као нормативни приручници зато што прате норму времена у којем су настали. ${ }^{2}$

Због свега тога мишљења смо да у српско-шпанским анализама треба постићи извесну сразмерност у погледу одабира речника и да се треба определити за оне шпанске речнике чија структура и намена најбоље одговарају наведеним речницма српског језика (по питању броја одредница, микроструктуре, начина описивања лексема, (не)укључености фразеолошких јединица које тражене лексеме творе итд.). У том смислу би, на пример, Матичином једнотомнику највише одговарали претходно наведени DUE, CLAVE или DEA, док би шестотомнику одговарао DRAE. ${ }^{3}$

Фразеографска издања на шпанском језику такође су бројна, а најрепрезентативнији је Документовани фразеолошки речник савременог шпанског језика Мануела Сека (DFDEA). Поред њега, у употреби су и Фразеолошки речник савременог шпанског језика Вареле и Кубарта (DFEM), Изреке и устаљени изрази Каљес Валеса (DFH), који је организован према тематским пољима. Бујтрагов Речник изрека и устаљених фраза (DDFH) поред објашњења значења нуди и могућа тумачења порекла израза, и у том смислу му у српском језику одговара књига Милана Шипке Зашто се каже. Посебно корисним како за контрастивно оријентисане анализе тако и за наставу шпанског као (не)матерњег језика сматрамо серију речника коју од 2002. године објављује ауторка Пенадес Мартинес (DLVEE, DLAEE, DLNAPEE). Она врши двојаку класификацију фразеологизама: с једне стране издваја њихове структурне типове (именичке, придевске, глаголске и прилошке), а с друге их дели према нивоу познавања језика на фраземе средњег, напредног или највишег језичког нивоа. ${ }^{4}$ Можемо се запитати је ли Пенадес Мартинес на овај начин дефинисала фразеолошки минимум шпанског језика (који би илустровале јединице средњег језичког нивоа), као и фразеолошки оптимум (који би одговарао јединицама највишег језичког нивоа).

\footnotetext{
${ }^{2}$ Шпански лингвисти се врло поносе својом лексикографском традицијом и сматрају да је Tesoro de la lengua castellana o española Себастјана Коварубијаса из 1611. године не само први једнојезични речник шпанског језика већ и први речник једног народног језика у Европи.

3 DRAE се узима као основни речнички параметар према ком се управљају остали речници сличне намене. Речник излази од 1780. године и до данас је доживео своја 23 издања (последње, 23. издање изашло је 2014. године). Овај речник је продукт сарадње Шпанске и свих других хиспанских академија које прате стандарднојезичку норму прописану граматикама и речницима Шпанске краљевске академије. Од 2001. године Речник има своје електронско издање, прилаз је потпуно слободан. Садржи приближно 200.000 одредница, од тога 19.000 тзв. американизама, односно речи карактеристичних за говор различитих земаља Јужне и Средње Америке (www.rae.es).

${ }^{4}$ Јасан је, дакле, ауторкин став према дидактици фразеолошких јединица, којима нема места у оквиру основних (почетних) курсева шпанског као страног језика. У савременим истраживањима срећу се и другачији ставови, према којима часови вокабулара од самог почетка учења језика треба да укључе и идиоматске и устаљене конструкције (увек имајући у виду њихову фреквентност употребе, синтаксичку структуру, прагматичке вредности, али и рецептивне и продуктивне способности ученика) (Наваро 2003, Гомес Молина 2000).
} 
2. Микроструктуралне специфичности одредница у једнојезичним речницима српског и шпанског језика

Микроструктура дескриптивних једнојезичних речника српског језика показује да пре дефиниције саме одреднице-лексеме они доносе граматичку информацију (на пример о роду именице, о броју уколико облик множине има специфичну морфологију, српски речници поред тога пружају информацију о глаголском виду и/или упућују на видски глаголски парњак). Затим указују на маркираност лексеме онда када њена употреба одудара од стандарднојезичке норме, и она се тада описује посебним квалификативима у зависности од својих функционално-стилских карактеристика (на пример необ. за необичну употребу лексеме). И општи речници шпанског језика садрже опис граматичких и дијасистемских обележја лексеме, а њихова маркација базира се на хронолошкој, спацијалној, социјалној основи, на регистру којем одредница припада. Поред тога, шпански речници дају и примере колокабилности лексеме, односно примере скупова у којима одредница често колоцира са другим речима. ${ }^{5}$ Будући да су дескриптивни речници усклађени с нормом времена у којем су настајали, у складу с тим је уређена и маркација одредница. Ово је нарочито интересантно у случају речника српског језика, који се не ажурирају често, па имамо пример првог тома PMC/MX, који је штампан пре отприлике педесет година. Упркос томе, PMC/MX и даље служи као валидан нормативни приручник, а из данашње перспективе може изненадити актуелност коришћених квалификатива и прецизност одређења фразеолошких јединица. Због свега тога српски речници се показују као нужно средство у истраживањима контрастивнојезичке природе. Након граматичких и дијасистемских обележја лексеме, дескриптивни речници дају њихову дефиницију, која може бити описне и/или синонимске природе.

На крају одреднице се у издвојеном реду даје скуп идиоматских израза у којима фигурира одређена лексема. Начин на који се они представљају у стандарднодескриптивним речницима ова два језика веома је сличан, и у њима не налазимо граматичку односно морфосинтаксичку категоризацију фразема, као ни контекстуализоване примере њихове употребе. Тиме је информација о дистрибутивним специфичностима и начину функционисања ових јединица у језику знатно сужена, али сматрамо да је то уобичајена пракса код оваквог типа речника.

И када упоредимо фразеолошке речнике ова два језика, до изражаја долази бројност шпанских фразеографских издања. У српском језику на располагању имамо Фразеолошки речник Ђорђа Оташевића, први модеран речник

${ }^{5}$ Постоје и комбинаторни или колокацијски речници (попут REDES-a), који настају из потребе да се „превазиђе празнина која настаје између дефиницијског одређења речи и начина на који ми говорници употребљавамо те речи” (из Предговора REDES-y). Они имају „ограничавајућу” улогу онда када значења речи нису нужно повезана са њиховом комбинаториком, што се види на примеру придевског пара maternal / materno (срп. матерински / матерњи / мајчински) који се исто дефинишу, али не употребљавају будући да кажемо instinto maternal (срп. мајчински инстинкт), али не и *instinto materno (*матерњи инстинкт), као што кажемо lengua materna

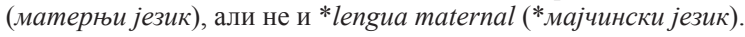


савременог стандардног језика. Како наводи са̂м аутор у Предговору: „Објашњења фразеологизама дата су парафразама које садрже високофреквентне (уобичајене) лексеме, морфосинтаксичке конструкције и семантичке везе савременог стандардног језика" (ФРСЈ: 7). Значењска компонента обрађених израза представља, дакле, централни део речничке микроодреднице, а дефиниција се, поред описних, спецификује и помоћу синонимских конструкција. Иако објашњења не остављају недоумице о значењској вредности израза, наилазимо и на спорадичне примере погрешно протумачених фразема. Тако је фразем доћи [некоме] из дупета (гузице) у главу одређен као израз који означава „изненада се сетити нечега, наумити нешто, неочекивано пасти на памет", док он, заправо, припада домену разборитости и доброг резоновања и означава „опаметити се, уразумити се, дозвати се памети”. ${ }^{6}$ Иако је назначено да је речник базиран на савременим формама српског језика, у њему фигурирају и фраземи застареле употребе (попут израза моћи се [некоме] најести таране с главе за „бити знатно виши од некога, знатно надилазити некога растом” или кад пукне будак више главе за „кад наступи смрт”), који пак не носе посебну маркацију. Речник не илуструје употребу фразема кроз контекстуализоване примере. Фразеолошки рјечник хрватскога или српскога језика Јосипа Матешића први је фразеолошки речник српскохрватског језика. Речник даје информације о стилистичким карактеристикама фразема само код израза ограничене употребе. Ипак, он у толикој мери садржи конструкције које се из данашње перспективе могу сматрати нестандардним (попут фразеологизама ограничене просторне и временске употребе које пак нису одређене као такве) да се данас тешко може говорити о њиховој правилној маркираности. Садржи 30.000 одредница, од којих је „око 12.000 обрађено" (из Предговора речнику), односно уз њихово објашњење дат је и контекст употребе. У Предговору аутор наводи да је потврду за изразе проналазио у изворној литератури, а када их није било могуће пронаћи на тај начин, вршио је проверу код „најмање два-три 'native spikera”” (FRHSJ: XIV).

Шпански фразеолошки речници углавном дају информацију о граматичкој природи фразема (DFDEA, DLVEE, DLAEE). Такође садрже ознаку којом се прецизирају функционално-стилска својства фразема, а неизоставно и квалификатор amer. ('американизам') за јединице које се употребљавају само на територији Хиспанске Америке или које тамо имају другачије или проширено значење. Даље, у шпанској фразеографској традицији егземплификација је саставни део речничке одреднице и не постоји фразеолошки речник без контекстуализованих примера употребе фразема. То нам умногоме олакшава разумевање њиховог значења и употребе. Начин егземплификације или навођења цитата може бити двојак. Документовани фразеолошки речник (DFDEA) наводи аутентичне примере употребе фразеолошких јединица углавном из прозних књижевних дела (и преузетих из CREA корпуса). У

\footnotetext{
${ }^{6}$ Значење које је наведено у речнику (,изненада се сетити нечега, наумити нешто, неочекивано пасти на памет") реализују изрази доћи у главу (односно дошло / дође [некоме] у главу), доћи у памет, односно пасти на памет, како је и забележено у речнику.
} 
осталим речницима (DFEM, DLVEE, DLAEE, DLNAPEE) цитати су ауторски односно редакцијски. ${ }^{7}$

Питање егземплификације директно нас наводи на промишљања о репрезентативности тих цитата. Неоспорно је да примери преузети из књижевних, махом прозних дела ауторитарних писаца, из тзв. ,језика добрих писаца" (попут DFDEA, PCAHУ, делимично FRHSJ) уживају већи углед зато што поштују критеријум ауторитета и нормативности. Они су кредибилнији, док редакцијски примери који се смишљају ad hoc (DFEM, DLVEE, DLAEE) подразумевају подешавање корпуса према ставу аутора, а не према начину на који се језик испољава. У том смислу они у потпуности зависе од идиолекта самог лексикографа, чиме се негира критеријум интерперсоналности, односно способности лексикографа да на основу масе појављивања одређене јединице апстрахује чињенице и утврди прецизно одређење језичке јединице. С друге стране, редакцијски примери понекад јасније и илустративније репрезентују значење и употребу израза. Ово се нарочито очитује у настави страних језика где је, на пример, студентима на средњем нивоу познавања језика далеко лакше да схвате семантичку и употребну вредност овако „уклопљених” цитата.

Ако се истраживање упери према самом корпусу, то знатно отежава прикупљање грађе, нарочито у случају анализе савремених језичких стања. Тада се неизбежно постављају питања: шта је то савремени језик, колики временски распон он обухвата на тој специфичној синхронијској равни, шта гарантује да се нека јединица употребљава у језику или да је ушла у језички систем, који су поуздани извори за потврду јединица савременог језика итд. Желимо ли представити реална језичка стања у датом моменту, чини се да се не могу заобићи говорни језик нити језик медија, који у великој мери укључују савремене језичке облике. Овде се можемо запитати и могу ли говорни језик и новински језик, који су до те мере изједначени да их је данас веома тешко јасно раздвојити, бити довољна потврда употребе језичких јединица. Разговорни језик, као најраспрострањенији варијетет говорног језика (Ристић 2006: 53), веома је актуалан предмет лингвистичких истраживања, при чему су превазиђене „предрасуде о његовој инфериорности у односу на друге видове језичке реализације" (Ристић 2006: 54). Ако поставимо за циљ постизање приближне сразмерности у врсти корпуса контрастираних језика, периодика се показује као најдоступнији извор, који, поред тога, илуструје реално стање у језику. Ипак, говорна форма савременог језика подразумева

${ }^{7}$ CREA корпус Шпанске академије (corpus.rae.es) једнојезични је корпус савременог језика. Постоје и други електронски корпуси отвореног приступа CORPES XXI (Корпус шпанског језика XXI века), CORDE (Дијахронијски корпус), CDH (Корпус новог историјског речника шпанског језика). Када имамо у виду да је с једне стране израда електронских корпуса шпанског језика као приоритетних државних пројеката институционално уређена и да на њима раде стотине истраживача, а да с друге стране израда јединог корпуса српског језика (SrpKor) у потпуности зависи од добре воље, могућности и ентузијазма појединаца, јасно је да не можемо говорити о упоредивости електронских корпуса на плану ова два језика. Поред једнојезичних, постоје и вишејезични, паралелни корпуси (попут linguee.com) где се један текст даје на више језика, те је могуће правити граматичке или терминолошке паралеле. Они се разликују од упоредних корпуca, у којима текстови фигурирају независно и исти текст се не преводи на различите језике. 
и настанак спорадичних израза који се употребе у једном тренутку (када се код аутора јави потреба за тим, када се жели појачати експресивност, када таква језичка манипулација одговара ширем комуникативном контексту, код игре речи итд.) и никада се више не понове. У процесу прикупљања грађе за фразеолошка истраживања проблем могу проузроковати тзв. оказионализми или ефемерни изрази, тзв. квазифраземи типа пошло му за ногом за „постигао је гол".

Дескриптивни и фразеолошки речници српског и шпанског језика представљају основни извор који се у истраживањима допуњује изразима из тзв. живог језика. То не морају бити нови, дотад некоришћени и незабележени изрази већ и они који нису увек прецизно (а понекад ни сасвим тачно) одређени. И српски и шпански језик имају фраземе који остају незабележени, што се види на примеру израза луда глава и шп. cabeza loca (досл. 'луда глава'). Његова употреба у српском језику потврђена је у SrpKor2013 корпусу (не и у речницима), док у шпанским речницима није забележено проширење значења овог израза. У оба језика они функционишу као карактеризатори човека и описују га као неразумног, непоузданог, незрелог. За оваквог човека шпански речници бележе ser un mala cabeza (досл. 'бити лоша глава') или tener mala cabeza (досл. 'имати лошу главу'), али не и cabeza loca. Израз cabeza loca је у DFDEA дефинисан као једнозначни израз, који описује жену лаког морала („неморална жена, лака жена”) и према овој речничкој дефиницији он са српским луда глава гради однос привидне еквиваленције, односно они су фразеолошки лажни пријатељи. Тек се претрагом електронских корпуса показује да се у савременом шпанском језику cabeza loca такође користи као денотат за непромишљено, неозбиљно и брзоплето понашање, и да је ово значење данас доминантно. Овај израз илуструје и како његова конотативна компонента може функционисати само у једном језику (у овом случају српском, јер прагматика израза показује да он може бити и позитивно обојен, као када се користи за исказивање наклоности према некоме чије су нам речи, понашање или поступци посебно драги и симпатични, често у директном обраћању).

\section{3. Закључак}

Лексиколошки и фразеолошки оријентисана контрастивна истраживања која пореде језичке јединице кроз паралелан опис неминовно се базирају на речницима тих језика. У данашњој ери дигитализације и нарочито међу млађом популацијом, штампани речници губе на значају пред многобројним електронским речницима и корпусима. На плану српског и шпанског језика дескриптивни једнојезични речници су незаобилазно средство у процесу формирања грађе. Они уједно служе и као нормативни приручници који садрже основну значењску и граматичку информацију о лексемама и фраземима, о проширењу њиховог значења, као и о њиховим функционално-стилским одликама; на тај начин нам помажу при решавању различитих недоумица. Фразеолошки речници, поред тога што одређују значење, углавном инфор- 
мишу и о употребним вредностима израза. У истраживањима која за предмет проучавања имају савремени језик ова основна, речничка грађа допуњује се изразима који се употребљавају у говорној форми, али остају недокументовани или недовољно прецизно описани у речницима. Контрастивна српско-шпанска истраживања приликом формирања грађе теже приближној сразмерности у употреби речника у погледу њихове структуре и намене. Понудили смо опис микроструктуралних карактеристика једнојезичних речника ових језика и осврнули се на питање формалних и садржинских (не)подударности одредница. Поред речника и електронски корпуси имају важну улогу у контрастивним истраживањима, првенствено као потврда за употребу језичких јединица, али је на плану ова два језика веома тешко постићи њихову упоредивост.

Анализе које се спроводе на основу лексикографских издања које смо представили у овом раду сматрамо веома важним за теоријску и практичну лексикографију, за билингвалну лексикографију, и нарочито за транслатологију, где правилно разумевање текста на изворном језику омогућава његово добро обликовање на циљном језику. Свесни тога да не постоји речник (штампани или електронски) који бележи све што постоји у неком језику, као и да је далеко лагоднија позиција корисника и критичара речника од позиције самих лексикографа, мишљења смо да истраживачи и сви други корисници речника кроз конструктивне коментаре на свој начин доприносе неговању језичке културе.

\section{ЛИТЕРАТУРА}

Гарсија-Пахе Санћеc 2008: М. García-Page Sánchez, Introducción a la fraseología española. Estudio de las locuciones, Barcelona: Anthropos.

Гомес Молина 2000: J. R. Gómez Molina, Las unidades fraseológicas del español: una propuesta metodológica para la enseñanza de las locuciones en la clase de ELE, Aprendizaje y enseñanza de una segunda lengua. Quaderns de Filologia, V, 111-134.

Ђорђевић 1983: R. Đorđević, Kontrastivna analiza i kontrastivna realnost, Kontrastivna analiza i nastava stranih jezika, Beograd: Društvo za primenjenu lingvistiku Srbije, 19-26.

Ђорђевић 2004: R. Đorđević, Uvod u kontrastiranje jezika, Beograd: Filološki fakultet.

Костић Томовић 2009: J. Kostić-Tomović, Jezička ekvivalencija i njeni tipovi, Prevodilac, 61, 21-41.

Михајловић 1970: Љ. Михајловић, Контрастивно проучавање језика, Кюижевност и језик, XVII/3-4, 334-340.

Наваро 2003: C. Navarro, Didáctica de las unidades fraseológicas, y: M.V.Calvi, F. San Vicente (yp.), Didáctica del léxico y nuevas tecnologías, ViareggioLucca: Mauro Baroni Ed., 99-115. 
Порто Дапена 2002: J. A. Porto Dapena, Manual de técnica lexicográfica, Madrid: Arco Libros.

Ристић 2006: С. Ристић, Раслојеност лексике српског језика и лексичка норма, Београд: Институт за српски језик Српске академије наука и уметности.

Станковић 2009: S. Stanković, O pojmu i razvoju kontrastivne analize jezika, $<$ http://scindeks-clanci.ceon.rs/data/pdf/0354-3293/2009/0354-3293093 9065S.pdf> 07.06.2014.

Станковић 2012: С. Станковић, Из контрастивне анализе језика: проблеми, резултати, класификација и примена, $<$ https://www.google.rs/url?sa=t\&rc $\mathrm{t}=\mathrm{j} \& \mathrm{q}=\&$ esrc $=\mathrm{s} \&$ source $=$ web $\& \mathrm{~cd}=1 \& \mathrm{cad}=\mathrm{rja} \&$ uact $=8 \& \mathrm{ved}=0$ ahUKEwi 44 aG2fTWAhWDCpoKHYURC1oQFggnMAA\&url=https\%3A\%2F\%2Fizd anja.filfak.ni.ac.rs\%2Fcasopisi\%2F2013\%2Fdownload\%2F569_05ead44e1 08bc5283b47117939684540\&usg=AOvVaw0DiRK-f6h71N9oWKycevDr $>$ 07.06.2014.

\section{РЕЧНИЦИ И КОРПУСИ}

Боске 2004: I. Bosque Muñoz, Redes. Diccionario combinatorio del español contemporáneo, Madrid: SM. [REDES]

Бујтраго 2000: A. Buitrago, Diccionario de dichos y frases hechas, Madrid: Espasa. [DDFH]

Варела, Кубарт 1996: F. Varela, H. Kubarth, Diccionario fraseológico del espanol moderno, Madrid: Gredos. [DFEM]

Каљес Валес, Бермејо Мелендес 2000: J. Calles Vales, B. Bermejo Meléndez, Dichos y frases hechas, Madrid: Libsa. [DFH]

CREA: Real Academia Española: Banco de datos, Corpus de Referencia del Español Actual (доступно на: http://www.rae.es) [CREA]

Малдонадо Гонсалес 2006: C. Maldonado González (уред.), Clave:diccionario de uso del español actual, Madrid: SM. [CLAVE]

Матешић 1982: J. Matešić, Frazeološki rječnik hrvatskoga ili srpskoga jezika, Zagreb: Školska knjiga. [FRHSJ]

Молинер 2002: M. Moliner, Diccionario de uso del español, I-II, Madrid: Gredos. [DUE]

Оташевић 2007: Ђ. Оташевић, Мали српски фразеолошки речник, Београд: Алма.

Оташевић 2012: Ђ. Оташевић, Фразеолошки речник српског језика, Нови Сад: Прометеј. [ФРСЈ]

Пенадес Мартинес 2002: I. Penadés Martínez, Diccionario de locuciones verbales para la enseñanza del español, Madrid: Arco Libros. [DLVEE]

Пенадес Мартинес 2005: I. Penadés Martínez, Diccionario de locuciones adverbiales para la enseñanza del español, Madrid: Arco Libros. [DLAEE] 
Пенадес Мартинес 2008: I. Penadés Martínez, Diccionario de locuciones nominales, adjetivas y pronominales para la enseñanza del español, Madrid: Arco Libros. [DLNAPEE]

RAE 2001: Diccionario de la Lengua Española, I-II, Madrid: Real Academia Española. [DRAE]

RAE: Real Academia Española, Diccionario de la Lengua Española (електронско издање), www.rae.es/recursos/diccionarios/drae [DRAEe]

Речник српскога језика 2007, Нови Сад: Матица српска. [РMC]

Речник српскохрватскога књижевног језика, 1967-1976, I-VI, Нови Сад, Загреб: Матица српска, Матица хрватска. [PMC/MX]

Секо де Арпе (et al) 1999: M. Seco de Arpe (et al.), Diccionario del español actual, I-II, Madrid: Aguilar. [DEA]

Секо де Арпе 2005: M. Seco de Arpe, Diccionario fraseológico documentado del español actual: locuciones y modismos españoles: basado en el Diccionario del español actual, Madrid: Aguilar. [DFDEA]

SrpKor2013: Д. Витас, М. Утвић, Корпус савременог српског језика (верзија SrpKor2013), Група за језичке технологије Универзитета у Београду (доступно на: http://www.korpus.matf.bg.ac.rs/korpus/).

Aneta G. Trivic

EL PAPEL DE LOS DICCIONARIO SERBIOS EN LAS INVESTIGACIONES CONTRASTIVAS EN EL PLANO DE LAS LENGUAS SERBIA Y ESPAÑOLA

\section{Resumen}

Este trabajo pertenece a las investigaciones lexicográficas. Examinamos el papel que los diccionarios monolingües (generales y fraseológicos) serbios ejercen en las investigaciones contrastivas. Bajo el marco de los análisis fraseológicos procuramos determinar las posibilidades de formación de un corpus paralelo en el plano de las lenguas serbia y española. Debido al número desproporcionado de las obras lexicográficas entre las dos lenguas intentamos consegir una proporcionalidad aproximada siguiendo el criterio de la estructura, función y propósito de los diccionarios analizados. Con este fin precisamos las especificidades microestructurales de los lemas y ofrecemos una visión crítica de diferentes características de los diccionarios comparados: la información gramatical y pragmatical, la inclusión de los ejemplos contextualizados, la represantatividad de los ejemplos recopilados, su actualidad, etc. Conscientes de que no existe el diccionario que documente una información completa sobre un lexema o frasema y de que es mucho más fácil criticar el trabajo de los lexicógrafos que ejercerlo, creemos que las observaciones constructivas de los investigadores y otros usuarios de los diccionarios contibuyen significativamente al cultivo de la cultura lingüística.

Palabras clave: lexicografía, diccionario general y fraseológico, microestructura del diccionario, corpus, análisis contrastivo, serbio, español. 